\title{
Myasthenia gravis in a reference Western Mexican Hospital: Comparison of a new cohort versus a historical one
}

\author{
Juan D. Parada-Garza1', Luis A. Miranda-García', José de J. González-Jaime², Amado Jiménez-Ruiz³, \\ Gabriela García-Almeida1', Germán López-Valencia', Héctor R. Pérez-Gómez4, and José L. Ruiz-Sandoval1,5* \\ ${ }^{1}$ Department of Neurology; ${ }^{2}$ Department of Rehabilitation; ${ }^{3}$ Internal Medicine; ${ }^{4}$ Department of Infectology. Hospital Civil de Guadalajara "Fray Antonio \\ Alcalde"; ${ }^{5}$ Department of Neurosciences, Centro Universitario de Ciencias de la Salud Universidad de Guadalajara. Guadalajara, Mexico
}

\begin{abstract}
Background: Myasthenia gravis (MG) is a post-synaptic autoimmune disease of the neuromuscular junction, whose cardinal manifestations are weakness and fatigue. Objective: The objective of the study was to report a cohort of patients with a diagnosis of MG in a West Mexican hospital and compare the clinical profile, diagnostic, and therapeutic approach and prognosis against a previously published cohort of the same hospital. Materials and methods: Consecutive patients included in two cohorts: the first one already published from 1999 to 2007 and the second one reported here from 2008 to 2018. Results: The most recent cohort included 39 patients, 23 women (59\%), with an average age of 50 years, and superior to the previous cohort (43 years). Hypertension (39\%) and diabetes (18\%) were observed with a marked increase in the current cohort. The distribution in the Osserman staging was very similar. The positivity of acetylcholine receptor antibodies (ACRA) increased from $37 \%$ to $88 \%$. In both cohorts, most patients received pyridostigmine and in two-thirds steroids. The previous cohort recorded $4 \%$ of patients treated with a steroid-sparing immunosuppressant, contrasting with $90 \%$ (azathioprine $85 \%$, and mycophenolate 5\%) of the current cohort. Thymectomy was a less frequent practice in $12 \%$. Mortality showed a significant decrease from $16 \%$ to $0 \%$. Conclusion: Differences were observed among the cohorts, highlighting in the most recent one a higher age, the appearance of chronic-degenerative diseases, greater positivity to ACRA, optimization of pharmacological management, less thymectomy, and no mortality. Replicas of this work in other hospital settings are pertinent.
\end{abstract}

Key words: Acetylcholine receptor antibodies. Mexico. Myasthenia gravis. Thymectomy.

\section{Miastenia gravis en un hospital de referencia del occidente de México: Comparación de una cohorte nueva versus una histórica}

\section{Resumen}

Antecedentes: La miastenia gravis (MG) es una enfermedad autoinmune postsináptica de la unión neuromuscular, cuyas manifestaciones cardinales son debilidad y fatiga. Objetivo: Reportar una cohorte de pacientes con diagnóstico de MG en un hospital del occidente de México y comparar el perfil clínico, el enfoque diagnóstico y terapéutico, y el pronóstico frente

Correspondence:

*José L. Ruiz-Sandoval

E-mail: jorulej-1nj@prodigy.net.mx
Available online: $21-10-2020$ Rev Mex Neuroci. 2020;21(5):180-186 www.revmexneurociencia.com 1665-5044/ @ 2020. Academia Mexicana de Neurología A.C. Published by Permanyer. This is an open access article under the CC BY-NC-ND license (http://creativecommons.org/licenses/by-nc-nd/4.0/). 
a una cohorte publicada previamente del mismo hospital. Material y métodos: Pacientes consecutivos incluidos en dos cohortes: la primera ya publicada (de 1999 al 2007) y la reportada aquí (del 2008 al 2018). Resultados: En la cohorte más reciente se incluyeron 39 pacientes, 23 mujeres (59\%), con edad promedio de 50 años, superior a la cohorte previa (43 años). Hipertensión arterial (39\%) y diabetes (18\%) se observan con marcado incremento en la cohorte actual. La distribución en la estadificación de Osserman fue similar. La positividad de los anticuerpos contra el receptor de acetilcolina (ACRA) aumentó del 37 al 88\%. En ambas cohortes la mayoría de los pacientes recibieron piridostigmina y dos terceras partes esteroides. La cohorte previa registró un $4 \%$ de pacientes tratados con inmunosupresores ahorradores de esteroides, contrastando con el 90\% (azatioprina 85\%, micofenolato 5\%) de la cohorte actual. La timectomía fue una práctica menos frecuente, en el $12 \%$. La mortalidad presentó un importante decremento, del 16\% al 0\%. Conclusión: Se observan diferencias entre las cohortes, destacando en la más reciente una mayor edad de presentación, aparición de enfermedades cronicodegenerativas, mayor positividad a ACRA, optimización del manejo farmacológico, menos timectomía y nula mortalidad. Son pertinentes réplicas de este trabajo.

Palabras clave: Anticuerpos contra receptor de acetilcolina. México. Miastenia gravis. Timectomía.

\section{Introduction}

Myasthenia gravis (MG) is a post-synaptic autoimmune disease of the neuromuscular junction with a classic bimodal presentation related to sex, most often affecting young women under 40 and men over 50 years of age ${ }^{1-5}$. Epidemiological data support an increase in its prevalence, which are explained by the presence of better diagnostic tools, greater sensitivity to diagnosis, and increased survival of patients. Thus, the prevalence from studies carried out in the 60's accounted for 0.77 cases per 100,000 inhabitants, while the most recent report a greater affectation in ranges between 13 and 25/100,000 ${ }^{1-6}$.

The objective of this study is to describe the clinical presentation, diagnostic, and therapeutic approaches, as well as the prognosis of patients with MG enrolled from years 2008 to 2018 in a reference hospital of West Mexico and compare the results against a historical cohort from years 1999 to 2007 in the same hospital, the latter already published in this journal'.

\section{Materials and methods}

All consecutive adult patients diagnosed with MG treated at the outpatient clinic of the Guadalajara Civil Hospital "Fray Antonio Alcalde" (HCG) in a 10-year period between January 2008 and August 2018 were captured. Hospitalized patients were also included in the analysis, as well as those referred by other services such as Internal Medicine, Rehabilitation, Geriatrics, and Intensive Therapy.

To establish the diagnosis of MG, patients had to comply at least one positive test of the following: (a) Tensilon test; (b) supramaximal repetitive nerve stimulation test (Jolly test); (c) ice pack test; (d) acetylcholine receptor antibodies (ACRA); and (e) muscle-specific kinase antibodies (anti-MuSK). In addition, sociodemographic factors, comorbid, clinical presentation, abnormalities to neurological examination, findings in complementary labs, medical treatment, surgical approach, histopathological results, complications, and death were taken into account.

The disease was staged using the Osserman scale: I (only ocular compromise, ptosis, and diplopia); Ila (moderate diffuse skeletal muscle involvement, generalized weakness, ptosis, and diplopia without respiratory deficit); Ilb (severe muscular involvement associated with ocular and bulbar involvement, marked weakness, dysphagia, dysarthria, and impaired mastication); III (rapidly progressive muscular involvement associated with ocular and bulbar muscle involvement, and with respiratory deficit); IV (chronic myasthenia with severe diffuse, ocular and bulbar muscle involvement, and resulting from types I, II, and III gradual progression) ${ }^{8}$.

Due to the bimodal presentation of the MG, the population was divided into four groups for analysis: $\leq 30$ versus $>30$ years of age and $\leq 50$ versus $>50$ years of age. The ethics committee in our hospital approved the study; as this is an observational study, not informed consent of the participants was required.

The resulting data were captured and analyzed using the SPSS v25.0 system. Pearson's Chi-squared test was used for nominal variables in the univariate analysis. The Mann-Whitney U-test was used to compare abnormally distributed continuous variables (determined by the Shapiro-Wilk test). The results with $p<0.05$ were considered significant.

In a retrospective and introspective analysis, the results were compared to a cohort of patients with MG published in this journal by Echeverría et al. in 2008, with data collected from the year 1999 to 2007, 
conducted in the same hospital (Guadalajara Civil Hospital "Fray Antonio Alcalde") and by the same chief investigator; the same inclusion criteria were applied to our cohort, except for that they did not include ice pack test and anti-MuSK in the diagnostic approach. For further information on this work, kindly consider look at the original article ${ }^{7}$. No patients of that previous article were included in this cohort. The observations of this comparison are the basis of the discussion.

\section{Results}

During the established period from 2008 to 2018, 50 patients with diagnosis of MG were initially considered, 11 were excluded because they had insufficient data for analysis or correspond to another diagnosis, resulting in a final 39 enrolled patients, 23 women $(59 \%)$ and 16 men $(41 \%)$, with a sex ratio of $1.4: 1$. The age range was between 17 and 80 years, with an average of 49.8 years, 48.5 for women, and 51.7 for men $(p=0.78)$. A total of $21(54 \%)$ patients were $>50$ years old and 8 (20.5\%) were $\leq 30$ (Table 1).

Regarding medical history, 15 patients (38.5\%) had systemic arterial hypertension and $7(18 \%)$ diabetes. Five patients (13\%) (four women and one man) had associated autoimmune disease: hypothyroidism, vitiligo, vitiligo plus hypothyroidism, pernicious anemia, and dermatomyositis. The staging of the disease was predominantly distributed in Grades I, Ila, and Ilb of Osserman, without significant differences with respect to sex; in the group of $\leq 30$ years, there was no Grade I cases $(p=0.04)$ (Table 1).

Important aspects in signs and symptoms were the presence of ptosis in $92 \%$ of cases, most frequently in women $(100 \%$ vs. $81 \%)(p=0.03)$; bilateral ptosis had a predominance in men (69\% vs. $30 \%)(p=0.02)$. Extraocular muscle paralysis at exploration was much more frequent in the group $>30$ years $(p=0.003)$ and in the group $>50$ years $(p=0.003)$ (Table 1).

Regarding MG diagnosis, the Tensilon test was positive in the only patient who was performed, while the supramaximal repetitive nerve stimulation test (Jolly test) was positive in 20 of the 24 patients evaluated $(83 \%)$. One case was diagnosed by the ice pack test. The ACRA analysis was performed on 34 patients, and the result was positive in 30 of them (88\%), while anti-MuSK were requested in two patients, both negative. Chest-computed tomography (CT) was performed in 30 patients, finding thymic alteration in 15 cases (50\%) (Table 1).
In total, 37 patients were treated with pyridostigmine $(95 \%)$ in a dose range of $90-540 \mathrm{mg}$ and an average of $184 \mathrm{mg}$. Corticosteroids were prescribed in varying doses to 27 patients (69\%), azathioprine (AZA) was indicated to 33 patients (85\%) in doses of $50-150 \mathrm{mg}$, with an average of $80 \mathrm{mg}$ and mycophenolate mofetil was only indicated to two patients $(5 \%)$. Two patients were treated with plasmapheresis and one with intravenous immunoglobulin for exacerbation of symptoms or diagnosis of myasthenic crisis (Table 1).

Surgical treatment (transsternal thymectomy) was performed in $16(41 \%)$ patients, being a little more frequent among men (56\% vs. $30 \%)$. This procedure was significantly more frequent in the group $\leq 30$ years compared to $>30$ years $(75 \%$ vs. $32 \%, p=0.02)$. Fourteen patients $(87.5 \%)$ presented benign histopathological findings: twelve $(75 \%)$ corresponded to thymic hyperplasia ( 7 women vs. 5 men, $p=0.04$ ) and $2(12.5 \%)$ to being thymoma; in the remaining two patients (12.5\%), malignant thymoma was reported (Table 1).

Information related to the follow-up of the cases was obtained in 31/39 patients, with an average of 32 months of follow-up (minimum of two and a maximum of 108 months). No deaths were reported at any time, even during exacerbations or myasthenic crises. Table 2 shows the comparison of patient's characteristics in the two cohorts, their diagnostic approach, medical and surgical treatment, histopathological findings, and mortality. The differences or similarities between are discussed below.

\section{Discussion}

MG had a mild predominance in women with a frequency almost equal to the previous cohort of $58 \%$; however, in both cohorts this figure is less than $60-88 \%$ of what was reported by other authors ${ }^{5,7,9-11}$. Regarding age, different publications in the past two decades in Mexico stand out for a growing average age of patients; the average age reported in 2002 was 32 years; in our previous cohort from 1999 to 2007 it was 43 years; another study of our group reported 47 years in 2010 and the current one, 50 years ${ }^{5}$. This aging of the population diagnosed with MG has also been observed in the United States, Europe, Japan, and China 2,5,7,12. The typical bimodal distribution associated with sex was not observed by our group; however, this may be associated with insufficient samples, since in a Mexican study of 2010 in which more than 500 cases were analyzed, the bimodal presentation was evident 5 .

Chronic-degenerative comorbidities (arterial hypertension and diabetes) significantly increased their frequency; 
Table 1. General description of the current cohort (2008-2018), according to sex and age group

\begin{tabular}{|c|c|c|c|c|c|c|c|c|c|c|}
\hline \multirow[t]{2}{*}{ Variables } & \multirow{2}{*}{$\begin{array}{l}\text { Total } \\
(n=39)\end{array}$} & \multicolumn{3}{|c|}{ Sex } & \multicolumn{3}{|c|}{ Age (years) } & \multicolumn{3}{|c|}{ Age (years) } \\
\hline & & $\begin{array}{c}\text { Male } \\
(n=16)\end{array}$ & $\begin{array}{l}\text { Female } \\
(\mathrm{n}=23)\end{array}$ & $\underset{\text { value }}{\mathbf{p}}$ & $\begin{array}{c}\leq 30 \\
(n=8)\end{array}$ & $\begin{array}{c}>30 \\
(n=31)\end{array}$ & $\begin{array}{c}\mathbf{p} \\
\text { value }\end{array}$ & $\begin{array}{c}\leq 50 \\
(n=18)\end{array}$ & $\begin{array}{c}>50 \\
(n=21)\end{array}$ & $\underset{\text { value }}{p}$ \\
\hline Female, $\mathrm{n}(\%)$ & $23(59)$ & $N / A$ & $23(100)$ & $\mathrm{N} / \mathrm{A}$ & $4(50)$ & $19(61)$ & - & $12(67)$ & $11(52)$ & - \\
\hline Male, n (\%) & $16(41)$ & $16(100)$ & $\mathrm{N} / \mathrm{A}$ & $\mathrm{N} / \mathrm{A}$ & $4(50)$ & $12(39)$ & & $6(33)$ & $10(48)$ & \\
\hline $\begin{array}{l}\text { Autoimmune } \\
\text { disease, } \mathrm{n}(\%)\end{array}$ & $5(13)$ & $1(6)$ & $4(17)$ & - & $0(0)$ & $5(16)$ & - & $4(22)$ & $1(5)$ & - \\
\hline Ptosis, n (\%) & $36(92)$ & $13(81)$ & $23(100)$ & 0.03 & $7(87)$ & $28(90)$ & - & $16(89)$ & $20(95)$ & - \\
\hline $\begin{array}{l}\text { Bilateral ptosis, } \\
\mathrm{n}(\%)\end{array}$ & $16 / 36$ (44) & $9 / 13(69)$ & $7 / 23(30)$ & 0.02 & $4 / 7$ (57) & $12 / 29(41)$ & - & $8 / 16(50)$ & $8 / 20(40)$ & - \\
\hline $\begin{array}{l}\text { Unilateral ptosis, } \\
\text { n (\%) }\end{array}$ & $20 / 36(56)$ & $4 / 13(31)$ & $16 / 23(70)$ & 0.02 & $3 / 7(43)$ & $17 / 19$ (59) & - & $8 / 16(50)$ & $12 / 20(60)$ & - \\
\hline $\begin{array}{l}\text { Extraocular muscle } \\
\text { paralysis, } \mathrm{n}(\%)\end{array}$ & $23(59)$ & $10(62)$ & $13(57)$ & - & $1(12.5)$ & $22(71)$ & 0.003 & $6(33)$ & $17(81)$ & 0.003 \\
\hline $\begin{array}{l}\text { Osserman at } \\
\text { arrival } \\
\text { I, n (\%) } \\
\text { Ila, n (\%) } \\
\text { lib, n (\%) } \\
\text { III, n (\%) } \\
\text { IV, n (\%) } \\
\text { Jolly (+), n (\%) } \\
\text { ACRA (+), n (\%) } \\
\text { CT scan (+), } \\
\text { n (\%) }\end{array}$ & $\begin{array}{c}11(28) \\
14(36) \\
13(33) \\
0(0) \\
1(2.6) \\
20 / 24(83) \\
30 / 34(88) \\
15 / 30(50)\end{array}$ & $\begin{array}{c}2(12) \\
8(50) \\
5(31) \\
0(0) \\
1(6) \\
7 / 9(78) \\
15 / 15(100) \\
9 / 14(64)\end{array}$ & $\begin{array}{c}9(39) \\
6(26) \\
8(35) \\
0(0) \\
0(0) \\
13 / 15(87) \\
15 / 19(79) \\
6 / 16(37)\end{array}$ & $\begin{array}{c}- \\
- \\
- \\
\text { N/A } \\
- \\
- \\
- \\
-\end{array}$ & $\begin{array}{c}0(0) \\
5(62) \\
3(38) \\
0(0) \\
0(0) \\
4 / 6(66) \\
6 / 7(86) \\
5 / 8(62)\end{array}$ & $\begin{array}{c}11(35) \\
9(29) \\
10(32) \\
0(0) \\
1(3) \\
16 / 18(89) \\
24 / 27(89) \\
10 / 22(45)\end{array}$ & $\begin{array}{c}0.04 \\
- \\
- \\
- \\
- \\
- \\
- \\
-\end{array}$ & $\begin{array}{c}3(17) \\
8(44) \\
7(39) \\
0(0) \\
0(0) \\
10 / 12(83) \\
13 / 14(93) \\
9 / 16(56)\end{array}$ & $\begin{array}{c}8(38) \\
6(29) \\
6(29) \\
0(0) \\
1(5) \\
10 / 12(83) \\
17 / 20(85) \\
6 / 14(43)\end{array}$ & $\begin{array}{l}- \\
- \\
- \\
- \\
- \\
- \\
- \\
-\end{array}$ \\
\hline $\begin{array}{l}\text { Medical treatment } \\
\text { Pyridostigmine, } \\
\text { n (\%) } \\
\text { Corticoids, n (\%) } \\
\text { Azathioprine, } \\
\text { n (\%) }\end{array}$ & $\begin{array}{l}37(95) \\
27(69) \\
33(85)\end{array}$ & $\begin{array}{l}15(94) \\
11(69) \\
14(87)\end{array}$ & $\begin{array}{l}22(96) \\
16(70) \\
19(83)\end{array}$ & - & $\begin{array}{l}8(100) \\
5(62) \\
7(87)\end{array}$ & $\begin{array}{l}29(94) \\
22(71) \\
26(84)\end{array}$ & $\begin{array}{l}- \\
- \\
-\end{array}$ & $\begin{array}{l}18(100) \\
12(67) \\
15(83)\end{array}$ & $\begin{array}{l}19(90) \\
15(71) \\
18(86)\end{array}$ & - \\
\hline $\begin{array}{l}\text { Thymectomy/ } \\
\text { histopathology } \\
\text { Thymectomy, } \\
\text { n (\%) }\end{array}$ & $16(41)$ & $9(56)$ & $7 / 23(30)$ & - & $6 / 8(75)$ & $10 / 31(32)$ & 0.02 & $10 / 18(56)$ & $6 / 21(29)$ & - \\
\hline $\begin{array}{l}\text { Benign, n (\%) } \\
\text { Hyperplasia, }\end{array}$ & $\begin{array}{l}14 / 16(87) \\
12 / 16(75)\end{array}$ & $\begin{array}{c}7 / 9(78) \\
5 / 9(55.5)\end{array}$ & $\begin{array}{l}7 / 7(100) \\
7 / 7(100)\end{array}$ & $\begin{array}{c}- \\
0.04\end{array}$ & $\begin{array}{l}6 / 6(100) \\
6 / 6(100)\end{array}$ & $\begin{array}{l}8 / 10(80) \\
6 / 10(60)\end{array}$ & - & $\begin{array}{l}9 / 10(90) \\
9 / 10(90)\end{array}$ & $\begin{array}{l}5 / 6(83) \\
3 / 6(50)\end{array}$ & $\begin{array}{l}- \\
-\end{array}$ \\
\hline $\begin{array}{l}\text { Benign } \\
\text { thymoma, n (\%) }\end{array}$ & $2 / 16(12.5)$ & $2 / 9(22)$ & $0 / 7(0)$ & - & $0 / 6(0)$ & $2 / 10(20)$ & - & $0 / 10(0)$ & $2 / 6(33.3)$ & - \\
\hline $\begin{array}{l}\text { Malignant } \\
\text { thymoma, n (\%) }\end{array}$ & $2 / 16(12.5)$ & $2 / 9(22)$ & $0 / 7(0)$ & - & $0 / 6(0)$ & $2 / 10(20)$ & - & $1 / 10(10)$ & $1 / 6(17)$ & - \\
\hline $\begin{array}{l}\text { Exacerbation, } \\
\mathrm{n}(\%)\end{array}$ & $5(13)$ & $3(19)$ & $2(9)$ & - & $1 / 8(12)$ & 4/31 (13) & - & $2(11)$ & $3(14)$ & - \\
\hline $\begin{array}{l}\text { Myasthenic } \\
\text { crisis, n (\%) }\end{array}$ & $5(13)$ & $4(25)$ & $1(4)$ & - & $1 / 8(12)$ & $4(31$ (13) & - & $1(6)$ & $4(19)$ & - \\
\hline
\end{tabular}

ACRA: acetylcholine receptor antibodies; CT: computed tomography; N/A: not apply; -: not significant.

moreover, diabetes is a new comorbid that was not observed in the previous cohort?. This is likely to reflect the usefulness of timely detection programs and/or be the result of the epidemiological and pandemic transition of chronic-degenerative diseases in our country, a proposal supported by the Mexico National Survey of Health and Nutrition Mid-way 2016 (ENSANUT MC 2016) ${ }^{13}$.

The associated diagnosis of autoimmune diseases had a slight increase of only $4 \%$ compared to the previous cohort $(9 \%)$; however, it continues to be 
Table 2. Comparison of the two evaluated cohorts

\begin{tabular}{|c|c|c|}
\hline Variable & $\begin{array}{c}\text { 1999-2007 } \\
\text { cohort }\end{array}$ & $\begin{array}{c}2008-2018 \\
\text { cohort }\end{array}$ \\
\hline Number of cases & 43 & 39 \\
\hline Female, $\mathrm{n}(\%)$ & $25(58)$ & $23(59)$ \\
\hline Average age, years & 43 & 50 \\
\hline Systemic arterial hypertension, $\mathrm{n}(\%)$ & 2 (4) & $15(38.5)$ \\
\hline Type II diabetes, n (\%) & $0(0)$ & $7(18)$ \\
\hline Autoimmune disease, $\mathrm{n}(\%)$ & 4 (9) & $5(13)$ \\
\hline $\begin{array}{l}\text { Osserman at arrival } \\
\text { I, } \mathrm{n}(\%) \\
\text { Ila, } \mathrm{n}(\%) \\
\mathrm{IIb}, \mathrm{n}(\%) \\
\mathrm{III}, \mathrm{n}(\%) \\
\text { IV, } \mathrm{n}(\%) \\
\text { Tensilon }(+), \mathrm{n}(\%) \\
\text { Jolly }(+), \mathrm{n}(\%) \\
\text { ACRA (+), } \mathrm{n}(\%) \\
\text { CT scan (+), } \mathrm{n}(\%) \\
\text { Pyridostigmine, } \mathrm{n}(\%) \\
\text { Corticoids, } \mathrm{n}(\%) \\
\text { Azathioprine, } \mathrm{n}(\%) \\
\text { Mycophenolate, } \mathrm{n}(\%) \\
\text { Thymectomy, } \mathrm{n}(\%)\end{array}$ & $\begin{array}{c}9(21) \\
14(33) \\
19(44) \\
1(2) \\
0(0) \\
13 / 13(100) \\
31 / 32(97) \\
14 / 38(37) \\
20 / 35(57) \\
43(100) \\
27(63) \\
2(4) \\
0(0) \\
23(53)\end{array}$ & $\begin{array}{c}11(28) \\
14(36) \\
13(33) \\
0(0) \\
1(2.6) \\
1(2.6) \\
20 / 24(83) \\
30 / 34(88) \\
15 / 30(50) \\
37(95) \\
27(69) \\
33(85) \\
2(5.1) \\
16(41)\end{array}$ \\
\hline $\begin{array}{l}\text { Histopathologic result } \\
\text { Normal, n (\%) } \\
\text { Hyperplasia, n (\%) } \\
\text { Benign thymoma, n (\%) } \\
\text { Malignant thymoma, n (\%) } \\
\text { Mortality, n (\%) }\end{array}$ & $\begin{array}{c}8 / 23(35) \\
11 / 23(48) \\
4 / 23(17) \\
0 / 23(0) \\
7(16)\end{array}$ & $\begin{array}{c}0 / 16(0) \\
12 / 16(75) \\
2 / 16(12.5) \\
2 / 16(12.5) \\
0(0)\end{array}$ \\
\hline
\end{tabular}

ACRA: acetylcholine receptor antibodies; CT: computed tomography.

$<15-22 \%$ reported by other series, including some from Mexico ${ }^{1,7,14,15}$. No cases of thyroiditis, systemic lupus erythematosus, or rheumatoid arthritis were identified, despite being three of the main autoimmune pathologies associated with MG'. This is a window of opportunity to emphasize a better autoimmune approach.

Although the majority of patients presented a generalized state of MG (stage II), the percentage was slightly lower than the previous cohort $(77 \%)^{7}$. Stage II was predominant in subjects under 30 years of age; nevertheless, this finding has not been well established in other studies that have rather shown a tendency toward both Stages I and II6,17.

In relation to specific signs and symptoms, there is no point of comparison, since these were not included in the 2008 cohort. The higher prevalence of extraocular muscle paralysis in older patients may be due to delayed treatment and disease progression during years without a diagnosis.
The Tensilon test showed a clear decrease in its performance, since it has been displaced by other more practical and less risky diagnostic methods. The repetitive nerve stimulation test continued to be a useful and frequently requested diagnostic method, especially in ACRA seronegative patients. Single fiber electromyography is the most sensitive tool for the diagnosis of MG, it is positive in $95 \%$ of patients with generalized MG and in 90-95\% with ocular MG; however, it is not yet available in West Mexico, a significant delay compared to other countries where is available in the majority of reference centers ${ }^{2,18,19}$. In a particular patient with high clinical suspicion, the diagnosis was made using the ice pack test (with high positive predictive value), after being negative for both ACRA and supra-maximal repetitive nerve stimulation test ${ }^{20}$.

$A$ very prominent point in our center is the increase in the percentage of positive ACRA patients (30 of 34 patients tested [88\%]) compared to the previous cohort (14 of 38 patients tested [37\%]). It is likely that at that time the detection of the antibodies by the local laboratory was deficient with respect to the methods and processing of the samples and therefore the results were unintentionally affected ${ }^{7}$. Although the percentage obtained here is very consistent with the reported worldwide, with $12 \%$ of cases being seronegative, anti-MuSK are not usually requested even though they represent $1-10 \%$ of cases; Ryanodine antibodies present in $70 \%$ of patients with thymoma and $M G$ are not available, neither do antibodies against lipoprotein receptor-related protein 4 found in $1-3 \%$ of cases $^{3,21}$. The percentage of thymic alteration in the CT scan was similar to the $57 \%$ of the previous cohort?

Almost all of our patients were treated with pyridostigmine. Corticosteroids continued to be used in two-thirds of the cases. An important advance was the increase in the use of steroid-sparing agents, administered to $90 \%$ of patients ${ }^{7}$. The medical management of MG in our hospital is consistent with the worldwide consensus of experts and data from controlled trials that support the use of prednisone in combination with AZA as a first-line treatment ${ }^{1,22}$. Good results have been obtained with the use of rituximab and should be considered, especially for refractory cases ${ }^{23,24}$.

Compared to the previous cohort (53\%), thymectomy was performed in a smaller number of patients, predominantly in men, younger subjects, and generalized stages ${ }^{7}$. Our patients were selected for surgery based on the CT findings, however, in patients with autoimmune MG without thymoma, thymectomy is performed 
as an option to avoid or minimize the dose and duration of immunosuppressants, if patients do not respond to an initial immunosuppressive trial or have intolerable side effects ${ }^{12,22,25}$. A recent study showed special benefit in patients with generalized disease, disease duration of $<3-5$ years, age of $<60-65$ years, and symptoms not completely relieved with anticholinesterase drugs ${ }^{1,10}$.

In addition, a report from the National Medical Center "20 de Noviembre" in Mexico found that there is a statistically significant improvement $(p=0.000)$ on the quantitative myasthenia gravis score scale when comparing the clinical condition of patients 1 year before versus 4 years after thymectomy ${ }^{26}$.

In this analysis, the frequency of thymic hyperplasia is consistent with that reported in other articles. Our thymoma percentage $(25 \%)$ is high, and we do not identify cases of thymic atrophy ${ }^{1,2,9,10,12}$. In contrast to the previous study (48\%), thymic hyperplasia represents a higher percentage, with a decrease in normal results, probably due to an improvement in sample processing; also, no cases of malignant thymoma were identified in the previous cohort?

Regarding prognosis, there is a clear decrease in mortality compared to the previous cohort, where it was recorded in $16 \% \%^{7}$. While it is true that there was a loss of follow-up in eight cases, there is certainty in the neurological staff and group that publish this report that no death was recorded in our hospital. A comparative analysis related to the prognosis with other hospitals in our country is not feasible due to the particular objectives of the studies or the small number of samples ${ }^{27,28}$. As a weakness, the response to treatment was not followed with validated functional scales; however, these will be included in prospective.

\section{Conclusion}

There are differences between the cohorts of our hospital, highlighting in the last one an older age of presentation, the appearance of chronic-degenerative diseases, greater positivity to ACRA, optimization of pharmacological management, less thymectomy, and no mortality. Much progress has been made in the diagnosis and treatment of MG in our hospital in the past decade; however, there still are areas of opportunity such as single-fiber electrodiagnosis, the realization of other non-ACRA antibodies and optimization of a flowchart for surgical treatment. We encourage the replicas of this work in others hospital centers.

\section{Acknowledgments}

The authors thank the Interinstitutional Program for the Strengthening of Research and Postgraduate of the Pacific (DELFÍN) for supporting the scientific formation of undergraduate doctors.

\section{Funding}

None.

\section{Conflicts of interest}

The authors declare they have no conflicts of interest in this study.

\section{Ethical responsibilities}

Protection of people and animals. The authors declare that no experiments were performed on humans or animals for this research.

Confidentiality of data. The authors declare that they have followed the protocols of their work center on the publication of patient data.

Right to privacy and informed consent. The authors declare that no patient data appear in this article.

\section{References}

1. Gilhus NE. Myasthenia Gravis. N Engl J Med. 2016;375:2570-81.

2. Lai $\mathrm{CH}$, Tseng HF. Nationwide population-based epidemiological study of myasthenia gravis in Taiwan. Neuroepidemiology. 2010;35:66-71.

3. Andersen JB, Heldal AT, Engeland A, Gilhus NE. Myasthenia gravis epidemiology in a national cohort; combining multiple disease registries. Acta Neurol Scand Suppl. 2014;129:26-31.

4. Carr AS, Cardwell CR, McCarron PO, McConville J. A systematic review of population based epidemiological studies in myasthenia gravis. BMC Neurol. 2010;10:46.

5. Tolosa-Tort P, Chiquete E, Domínguez-Moreno R, Vega-Boada F, Reyes-Melo I, Flores-Silva F, et al. Miastenia gravis (MG) en adultos de instituciones pertenecientes al sistema público sanitario Mexicano: un análisis de egresos hospitalarios durante el año 2010. Gac Med Mex. 2015;151:47-53.

6. Phillips $\mathrm{LH} 2^{\text {nd }}$. The epidemiology of myasthenia gravis. Ann N Y Acad Sci. 2003;998:407-12.

7. Echeverría-Galindo G, Mardueño-lbarra MT, González-Jaime JJ, Márquez-Magaña I, Erwin C, Sandoval-Virgen F, et al. Miastenia gravis en un hospital de referencia del occidente de México. Rev Mex Neurocir. 2008:9:278-82.

8. Osserman KE. Myasthenia Gravis. New York: Grune \& Stratton; 1958. p. 80.

9. García-Ramos G, Téllez-Zenteno JF, Zapata-Zúñiga M, Yamamoto-Furusho JK, Ruiz-Morales JA, Villarreal-Garza C, et al. HLA class II genotypes in Mexican mestizo patients with myasthenia gravis. Eur $\mathrm{J}$ Neurol. 2003;10:707-10.

10. Navarro-Reynoso F, Pérez-Romo A, Green L, Páramo-Arroyo R, Cicero-Sabido R. Resultados de la timectomía máxima en miastenia gravis. Experiencia de 20 años en el servicio de neumología y cirugía de tórax en el hospital general de México. Influencia de la timectomía en dosis de piridostigmina y tres variables espirométricas en miastenia gravis. Rev Inst Nac Enfem Respir Mex. 2006;19:252-7.

11. Grob D, Brunner N, Namba T, Pagala M. Lifetime course of myasthenia gravis. Muscle Nerve. 2008:37:141-9.

12. Remes-Troche JM, Téllez-Zenteno JF, Estañol B, Garduño-Espinoza J, García-Ramos G. Thymectomy in myasthenia gravis: response, complications, and associated conditions. Arch Med Res. 2002;33:545-51. 
Rev Mex Neuroci. 2020;21(5)

13. Hernández-Ávila M, Rivera-Dommarco J, Shamah-Levy T, Cuevas-Nasu L, Gómez-Acosta LM, Gaona-Pineda E, et al. Encuesta Nacional de Salud y Nutrición de Medio Camino 2016. Informe Final de Resultados. Mexico: Instituto Nacional de Salud Pública; 2012.

14. Cacho-Díaz B, Ruano-Calderón LA, Valdez-Ferrer SI, Porras M, García-Ramos G, Cantú-Brito C. Miastenia gravis y sus comorbilidades. Rev Mex Neurocir. 2006;7:449-50.

15. Nacu A, Andersen JB, Lisnic V, Owe JF, Gilhus NE. Complicating autoimmune diseases in myasthenia gravis: a review. Autoimmunity. 2015;48:362-8

16. Barraud C, Desguerre I, Barnerias C, Gitiaux C, Boulay C, Chabrol B. Clinical features and evolution of juvenile myasthenia gravis in a French cohort. Muscle Nerve. 2018;57:603-9.

17. Vanikieti K, Lowwongngam K, Padungkiatsagul T, Visudtibhan A, Poonyathalang $A$. Juvenile ocular myasthenia gravis: presentation and outcome of a large cohort. Pediatr Neurol. 2018;87:36-41.

18. Oh SJ, Kim DE, Kuruoglu R, Bradley RJ, Dwyer D. Diagnostic sensitivity of the laboratory tests in myasthenia gravis. Muscle Nerve. 1992;15:720-4

19. Meriggioli MN, Sanders DB. Myasthenia gravis: diagnosis. Semin Neurol. 2004;24:31-9.

20. Ramírez-Antúnez AG, García-Ramos G, Estañol-Vidal B, Juárez-Flores A. Validación de la prueba de hielo en oftalmoparesia por miastenia grave. Rev Neurol. 2013;57:385-95.
21. Meriggioli MN, Sanders DB. Muscle autoantibodies in myasthenia gravis: beyond diagnosis? Expert Rev Clin Immunol. 2012;8:427-38.

22. Sanders DB, Wolfe GI, Benatar M, Evoli A, Gilhus NE, Illa I, et al. International consensus guidance for management of myasthenia gravis: executive summary. Neurology. 2016;87:419-25.

23. Chan F, Swayne A, Gillis D, Walsh M, Henderson RD, McCombe PA, et al. Long-term follow-up of patients with myasthenia gravis treated with low-dose rituximab. J Neurol Neurosurg Psychiatry. 2019;90:955-6.

24. Guido G, Núñez-Orozco L. Experiencia clínica con rituximab en el manejo de pacientes con miastenia gravis refractaria a tratamiento convencional. Rev Mex Neurocir. 2011;12:340-5.

25. Wolfe GI, Kaminski HJ, Aban IB, Minisman G, Kuo HC, Marx A, et al Randomized trial of thymectomy in myasthenia gravis. $\mathrm{N}$ Engl $\mathrm{J}$ Med. 2016;375:511-22.

26. Hernández-Zepeda A, Plascencia-Álvarez NI, Aguilar-Juárez PA, Nuñez-Orozco L. Evaluación de la respuesta clínica en pacientes con miastenia gravis generalizada que se someten a timectomía en el CMN 20 de noviembre. Rev Mex Neurocir. 2016;17:S1-346.

27. Gutierrez-Manjarrez F, Barrera-Pacheco J, Garcia-Grimshaw MA, Moreno-Guillen A, Espinosa-Flores MA, Loya-Ceballos M, et al. Miastenia gravis en un hospital del norte de México. Rev Mex Neurocir. 2017;18:S1-320.

28. Pérez-Careta MD, González-Muñoz A, Ruiz-Franco AE. Miastenia gravis: serie de casos en el hospital Juárez de México. Rev Mex Neurocir. 2016;17:S1-346. 